\title{
Entomocidal effectiveness of some indigenous botanicals' aqueous extracts against maize weevil, Sitophilus zeamais (Motschulsky) (Coleoptera: Curculionidae)
}

\author{
Muhammad Mamoon-ur-Rashid ${ }^{1 *}$, Riaz-ud-Din ${ }^{1}$, Muhammad Tariq ${ }^{2}$, \\ Asghar Ali Khan ${ }^{3}$ and Muhammad Qasim Kakar ${ }^{4}$ \\ 1. Department of Entomology, Gomal University, Dera Ismail Khan-Pakistan \\ 2. Department of Entomology, PMAS Arid Agriculture University, Rawalpindi-Pakistan \\ 3. Department of Agronomy, Gomal University, Dera Ismail Khan-Pakistan \\ 4. Agriculture and cooperatives department Balochistan-Pakistan \\ *Corresponding author's email: mamoondik@yahoo.com \\ Citation \\ Muhammad Mamoon-ur-Rashid, Riazuddin, Muhammad Tariq, Asghar Ali Khan and Muhammad Qasim Kakar. \\ Entomocidal effectiveness of some indigenous botanicals' aqueous extracts against maize weevil, Sitophilus zeamais \\ (Motschulsky) (Coleoptera: Curculionidae). Pure and Applied Biology. Vol. 9, Issue 1, pp664-673. \\ http://dx.doi.org/10.19045/bspab.2020.90072
}

Received: 18/05/2019

Revised: $25 / 10 / 2019$

Accepted: 28/11/2019

Online First: 20/12/2019

\section{Abstract}

As part of efforts to explore environmental friendly alternatives to synthetic chemicals, aqueous extracts of Azadirachta indica, Caralluma tuberculata, Allium sativum, Curcuma longa, Citrulus colocynthis and Calotropis procera were used to investigate the entomotoxicity of selected plant materials against maize weevil, Sitophilus zeamais in stored maize. In order to investigate the effect of selected plant materials on the mortality of maize weevil, maize seeds $(20 \mathrm{~g})$ were treated with $0.5,1,1.5,2,2.5$ and $3 \% \mathrm{v} / \mathrm{w}$ of aqueous extracts in the laboratory of Entomology Department, Faculty of Agriculture, Gomal University, Dera Ismail Khan, Pakistan under controlled environmental conditions of $27 \pm 1^{\circ} \mathrm{C}$ and $65 \pm 2 \% \mathrm{R} . \mathrm{H}$ and 12 : 12 hour dark: light regimes. Experiment was laid out in Completely Randomized Design with five replications. The adult mortality of $S$. zeamais was recorded after 1 day, 2 days, 3 days, 7 days, 14 days and 21days, post exposure time period. The A. indica and $C$. longa plant aqueous extracts were found more toxic to adult maize weevil compared to other plant extracts recording (95\%) and (91\%) mortality at $3 \%$ concentration whereas; minimum adult mortality was recorded in C. procera (26\%) at 3\% concentration after 21 days' time span compared with control (2\%). The toxicity of the selected plant materials increased with increase in the concentration and exposure period. It is concluded from the present findings that the aqueous extracts of $A$. indica and $C$. longa can be used as safe alternative to chemical insecticides for the management of maize weevil under storage conditions.

Keywords: Maize weevil; Entomotoxicity; Exposure period; Plant materials; Stored maize

Introduction

Maize (Zea mays. L) is the highest yielding and the most versatile emerging cereal crop having wide adaptation under various agro- climatic conditions of tropical and sub-tropical regions across the globe [1]. Maize crop is a rich source 
of nutrients such as fats, proteins, carbohydrates, minerals and vitamins [2]. Among cereal crops, maize stands at $3^{\text {rd }}$ position after wheat and rice cultivation in Pakistan [3]. Maize crop was cultivated on an area of 1144 thousand hectares with a total production of 2920 thousand tones during 2015-2016 growing season [4].

Among the insect pests of stored grains, maize weevil (Sitophilus zeamais Motsch. (Coleoptera: Curculionidae) is the most devastating pest of maize. It is polyphagous in nature and found in tropical and sub-tropical regions of the world. Maize weevil infests maize grains both in field as well as during storage conditions. Maize weevil causes grain losses ranging from 20 to $90 \%$ during storage and it may infest 80 percent stored maize $[2,5]$. The maize weevil caused $37.51 \%$ grain damage and $33.23 \%$ weight losses in Dera Ismail Khan and its adjacent Punjab province areas [6].

Many methods have been developed to control maize weevil but its control is mainly achieved by the successive use of synthetic chemicals in the form of fumigants having quick knockdown effect. The use of synthetic chemicals causes many problems like resurgence of pests, residual effects on stored grains, lead to accumulation of residues on maize grains causing environmental and health hazards to human beings $[7,8]$. Furthermore, methyl bromide has been banned internationally by "Montreal International Agreement" due to its depletion effect on ozone layer [6]. To address the problems caused by synthetic insecticides scientists are trying to develop alternate control methods which are eco-friendly, economic, less health hazardous and readily available [9].

In present investigation, studies were conducted to investigate the entomotoxicity of six plant aqueous extracts including Azadirachta indica (Neem-seed), Caralluma tuberculata (bitter cress-succulent leaf), Allium sativum (Garlic-rhizome), Citrulus colocynthis (Bitter Apple fruit), Curcuma longa (TurmericRhizome), Calotropis procera (Ak-leaves) against maize weevil.

\section{Materials and methods Insect cultures}

The maize weevil were cultured on maize grains in the laboratory of Entomology department, Gomal University, Dera Ismail Khan, Pakistan. The maize grains (CV Azam White) used for culturing maize weevil were sterilized in a deep freezer maintained at $-20 \pm$ $2{ }^{\circ} \mathrm{C}$ for two weeks, to remove chances of previous infestation following standard method [10]. Maize grains were thoroughly cleaned before using in the trials. Two hundred pairs of newly emerged adult weevils were introduced in each jar and were maintained at $27 \pm 2{ }^{\circ} \mathrm{C}$ and $65 \pm 5 \%$ relative humidity under $12: 12$ hour day length (L:D). The plastic jars were covered with muslin cloth tightened with rubber band in order to prevent the insects from escaping and to facilitate the exchange of gases and were later placed in an incubator for 10 days. Afterwards, these insects were removed by sieving and were introduced to other jars for multiplication. The jars having infested maize grains were kept in incubator for 20 days. Newly emerged adult weevils were collected and kept in separate jars according to their age. Adults that emerged on same day were used for experimental purpose.

\section{Plant Aqueous Extracts preparation}

The plant materials (A. indica, C. tuberculata, $A$. sativum, $C$. longa, $C$. colocynthis and $C$. procera) used in this experiment were obtained from local market and brought to the laboratory of Entomology Department, Faculty of Agriculture Gomal University Dera Ismail Khan Pakistan. Plant materials were thoroughly washed with distilled water and were dried under shade in ventilated area till reaching constant weight. The outcome products were crushed/milled in an electric grinder and sieved with mesh having $2 \mathrm{~mm}$ size to get fine powders. The aqueous extracts for each treatment were prepared by using $0.5,1$, $1.5,2,2.5$ and 3 grams of each plant powder in $100 \mathrm{ml}$ of distilled water for 24hours in $250 \mathrm{ml}$ conical flask for 30 minutes and peculated via Whateman No. $1(9 \mathrm{~cm})$ filter paper. The filtered products were stored in plastic containers after 
due tagging and refrigerated till required for experimentation [11].

Entomotoxicity of various plant aqueous extracts against maize weevil

Aqueous extracts were used at six different concentrations of $0.5,1,1.5,2,2.5$ and $3 \%$, respectively and applied to 20grams of maize grains in plastic jars (200ml capacity) for each treatment. The aqueous extracts were stirred gently with glass rod for 4 to 5 minutes in order to ensure uniform distribution of extracts on the grains. The treated maize grains were removed from the plastic jars containing the aqueous extracts and were kept for 1hour on blotting paper in order to dry the seeds before the start of trials. For control, 20grams seeds were treated with distilled water only and were kept in separate jars.

Ten pairs of newly emerged adult weevils were introduced in each plastic jar. The muslin cloth was used to cover the plastic jars and tightened up with rubber bands in order to provide aeration and halt the passage of weevils from the jars. Experiment was arranged in Completely Randomized Design (CRD), with five replications for each treatment.

To record the data on the mortality of adult weevils, the number of dead insects were counted after 1, 2, 3, 7, 14 and 21days, respectively, after treatment. The cumulative mortality of the weevils was assessed by using Abott's (1925) formula:

Where: $\mathrm{PT}=\left(\mathrm{P}_{\mathrm{o}}-\mathrm{P}_{\mathrm{c}}\right) /\left(100-\mathrm{P}_{\mathrm{c}}\right), \mathrm{PT}=$ percentage of corrected mortality, $\mathrm{P}_{0}=$ percentage of observed mortality, $\mathrm{P}_{\mathrm{c}}=$ Percentage of control mortality

\section{Statistical analysis}

Recorded data were subjected to analysis of variance (ANOVA) and means were separated by applying least significant difference (LSD) test at $(\mathrm{P}<0.05)$. One way (ANOVA) was applied to investigate the effectiveness of treatment and varied concentrations of plant aqueous extracts against maize weevil. All statistical analyses were conducted by using STATISTIX version 8.1.

\section{Results \\ Mortality of maize weevil after 1 day}

The effect of different treatments at all the evaluated concentrations except the highest $(3 \%)$ on the adult mortality of maize weevil after 1day exposure period was nonsignificantly different $(\mathrm{P}>0.05) \quad$ (Table 1). Among the treatments, the A. indica and $C$. longa aqueous extracts indicated the highest adult mortality of $7.00 \%$ followed by $A$. sativum $(5.00 \%)$ at the highest concentration whereas no mortality was recorded on untreated maize grains. The efficacy of the treatments was in the sequence of $A$. indica and C. longa $>$ A. sativum $>C$. colocynthis $>C$. tuberculata $>C$. procera compared with control. The efficacy of the treatments increased linearly with increasing the concentration of the evaluated extracts. Maximum concentration (3\%) of $A$. indica was found most effective causing $7.00 \%$ mortality of the targeted insect followed by $2.5,2,1.5,1$ and $0.5 \%$ causing $6.00,5.00,3.00,3.00$ and $2.00 \%$ adult mortality, respectively. No mortality was registered in control treatment having untreated maize grains.

Mortality of maize weevil after 2 days

After an exposure period of 2 days, the maximum adult mortality of maize weevil (23\%) was observed in A. indica treated maize grains which differed significantly from all other treatments followed by C. longa $(18 \%)$ at $3 \%$ concentration. Among the treatments, the minimum adult mortality of $6.00 \%$ was recorded on maize grains treated with $C$. procera aqueous extracts which differed nonsignificantly from $8.00 \%$ mortality in $C$. colocynthis treated maize grains. No mortality was observed when maize weevil was reared on untreated maize grains. The efficacy of the treatments decreased with decreasing the concentration of the selected botanical extracts. Among the tested concentrations, the highest concentration (3\%) was found most effective, whereas; the lowest concentration $(0.5 \%)$ was found least effective against the weevils (Table $2)$. The efficacy of the treatments was found in the array of $A$. indica and $C$. longa $>A$. sativum $>C$. colocynthis $>C$. tuberculata $>C$. procera 
compared with control.

\section{Mortality of maize weevil after 3 days}

Table 3 presents the mortality of maize weevil after 3 days exposure period on maize grains treated with different concentrations of botanical extracts. From the results shown, it was observed that the mortality of maize weevil increased with increase in the concentration and exposure period to treated grains. The highest adult mortality (43.00\%) of weevil was recorded on maize grains treated with $3 \%$ concentration of $A$. indica extracts which was followed by $(27.00 \%)$ mortality at the highest concentration of $C$. longa extracts and $2.5 \% \mathrm{~A}$. indica and $C$. longa extracts $(26.00$ and $22.00 \%$ ). Among the treatments the least mortality was observed in $C$. procera and $C$. colocynthis extracts at all the evaluated concentrations. No. mortality of the weevils was observed in untreated maize grains.

Mortality of maize weevil after 7days

At 7days after treatment, significant increase in the efficacy of botanical extracts against weevils was recorded (Table 4). Among the treatments, $A$. indica and $C$. longa extracts were found the most effective at all the evaluated concentrations ranging from 0.5 to $3 \%$, whereas the $C$. tuberculata and $C$. procera extracts were found the least effective. The highest adult mortality of $78 \%$ was recorded on maize grains treated with $A$. indica extracts followed by $C$. longa (70\%) and $A$. sativum $(50.00 \%)$ extracts whereas minimum adult mortality of $21 \%$ was observed in $C$. procera treated grains at $3 \%$ compared with control $(2 \%)$.

\section{Mortality of maize weevil after 14 days}

Table 5 shows that all the evaluated plant aqueous extracts significantly affected $(\mathrm{P}<0.05)$ the mortality of adult weevils at 14 days after exposure compared with control. The maximum adult mortality of $88 \%$ was observed in $A$. indica treated maize grains followed by $C$. longa $(78 \%)$ and the least (23\%) was observed in $C$. procera treated grains at maximum concentration of $3 \%$ compared with control (2 $\%)$. Among the evaluated plant aqueous extracts $A$. indica and $C$. longa extracts caused maximum mortality whereas $C$. tuberculata and $C$. procera extracts caused minimum mortality of maize weevil. The A. indica extracts registered more than $50 \%$ mortality of weevils at all the evaluated concentrations except the lowest concentration of $0.5 \%$, whereas $C$. longa extracts caused more than $50 \%$ mortality at concentrations ranging from 1.5 to $3 \%$. The A. sativum extracts resulted into $53.00 \%$ mortality of weevils at highest concentration of $3 \%$. All other treatments at the evaluated concentrations could not register $\geq$ $50 \%$ mortality of weevils.

\section{Mortality of maize weevil after 21 days}

It is clear from the results that the mean percent mortality is directly proportional to the exposure period and concentration of evaluated extracts. Although none of the tested plant extracts caused $100 \%$ adult mortality, the $A$. indica extracts caused $95.00 \%$ adult mortality which differed non-significantly from $91.00 \%$ adult mortality in $C$. longa extracts followed by $60.00 \%$ mortality on A. sativum treated grains at maximum concentration of $3 \%$. Among the evaluated treatments, the $A$. indica and $C$. long $a$ extracts caused $\geq 50 \%$ adult mortality at concentrations ranging from 1 to $3 \%$. All other evaluated plant extracts caused < 50\% mortality of weevils at all the evaluated concentrations except $A$. sativum extracts at $2.5 \%$ causing $54.00 \%$ weevil mortality. Among the treatments, $C$. tuberculata and $C$. procera were found the least effective treatments against the tested insect. Overall, at 21 days after exposure, the lowest adult mortality of $0.23 \%$ was recorded when maize weevil was reared on untreated maize grains (Table 6). 
Table 1. Mean mortality (\%) of maize weevil due to different plant aqueous extracts and its varying concentrations on maize grains after 1 day exposure period

\begin{tabular}{|c|c|c|c|c|c|c|}
\hline \multirow{2}{*}{ Treatments } & \multicolumn{5}{|c|}{ Concentrations (\%) } \\
\cline { 2 - 7 } & $\mathbf{0 . 5}$ & $\mathbf{1}$ & $\mathbf{1 . 5}$ & $\mathbf{2}$ & $\mathbf{2 . 5}$ & $\mathbf{3}$ \\
\hline Azadirachta indica & $2.00 \pm 2.73^{\mathrm{NS}}$ & $3.00 \pm 2.73^{\mathrm{NS}}$ & $3.00 \pm 2.73^{\mathrm{NS}}$ & $5.00 \pm 0.00^{\mathrm{NS}}$ & $5.00 \pm 2.23^{\mathrm{NS}}$ & $7.00 \pm 2.73 \mathrm{a}$ \\
\hline Caralluma tuberculata & $0.00 \pm 0.00$ & $0.00 \pm 0.00$ & $1.00 \pm 2.23$ & $1.00 \pm 2.23$ & $2.00 \pm 2.73$ & $2.00 \pm 2.73 \mathrm{~cd}$ \\
\hline Allium sativum & $1.00 \pm 2.23$ & $2.00 \pm 2.73$ & $2.00 \pm 2.73$ & $3.00 \pm 2.73$ & $4.00 \pm 4.18$ & $5.00 \pm 0.00 \mathrm{ab}$ \\
\hline Curcuma longa & $2.00 \pm 2.73$ & $3.00 \pm 2.73$ & $3.00 \pm 2.73$ & $4.00 \pm 2.23$ & $4.00 \pm 0.00$ & $7.00 \pm 2.73 \mathrm{a}$ \\
\hline Citrullus colocynthis & $1.00 \pm 2.23$ & $1.00 \pm 2.23$ & $2.00 \pm 2.73$ & $2.00 \pm 2.73$ & $2.00 \pm 2.73$ & $4.00 \pm 2.23 \mathrm{bc}$ \\
\hline Calotropis procera & $0.00 \pm 0.00$ & $0.00 \pm 0.00$ & $0.00 \pm 0.00$ & $0.00 \pm 0.00$ & $1.00 \pm 2.23$ & $2.00 \pm 2.73 \mathrm{~cd}$ \\
\hline Control & $0.00 \pm 0.00$ & $0.00 \pm 0.00$ & $0.00 \pm 0.00$ & $0.00 \pm 0.00$ & $0.00 \pm 0.00$ & $0.00 \pm 0.00 \mathrm{~d}$ \\
\hline LSD Value & 2.04 & 3.56 & 3.89 & 5.44 & 5.19 & 2.89 \\
\hline
\end{tabular}

Each value is a mean \pm standard error of five replications. Means followed by the same letters along the column are not significantly different at (P>0.05) using LSD Test

Table 2. Mean cumulative mortality $(\%)$ of maize weevil due to different plant aqueous extracts and its varying concentrations on maize grains after 2 days exposure period

\begin{tabular}{|c|c|c|c|c|c|c|}
\hline \multirow{2}{*}{ Treatments } & \multicolumn{5}{|c|}{ Concentrations (\%) } \\
\cline { 2 - 7 } & $\mathbf{0 . 5}$ & $\mathbf{1}$ & $\mathbf{1 . 5}$ & $\mathbf{2}$ & $\mathbf{2 . 5}$ & $\mathbf{3}$ \\
\hline Azadirachta indica & $4.00 \pm 2.23 \mathrm{a}$ & $10.00 \pm 3.53 \mathrm{a}$ & $12.00 \pm 2.73 \mathrm{a}$ & $19.00 \pm 4.18 \mathrm{a}$ & $20.00 \pm 3.53 \mathrm{a}$ & $23.00 \pm 2.73 \mathrm{a}$ \\
\hline Caralluma tuberculata & $0.00 \pm 0.00 \mathrm{~b}$ & $2.00 \pm 2.73 \mathrm{~d}$ & $3.00 \pm 2.73 \mathrm{de}$ & $4.00 \pm 2.23 \mathrm{de}$ & $5.00 \pm 0.00 \mathrm{~d}$ & $7.00 \pm 2.73 \mathrm{~d}$ \\
\hline Allium sativum & $2.00 \pm 2.73 \mathrm{ab}$ & $6.00 \pm 2.23 \mathrm{bc}$ & $6.00 \pm 2.23 \mathrm{~cd}$ & $8.00 \pm 2.73 \mathrm{c}$ & $11.00 \pm 4.18 \mathrm{c}$ & $13.00 \pm 12.73 \mathrm{c}$ \\
\hline Curcuma longa & $3.00 \pm 2.73 \mathrm{a}$ & $8.00 \pm 2.73 \mathrm{ab}$ & $10.00 \pm 3.53 \mathrm{ab}$ & $12.00 \pm 2.73 \mathrm{~b}$ & $16.00 \pm 4.18 \mathrm{~b}$ & $18.00 \pm 2.73 \mathrm{~b}$ \\
\hline Citrullus colocynthis & $2.00 \pm 2.73 \mathrm{ab}$ & $3.00 \pm 2.73 \mathrm{~cd}$ & $7.00 \pm 2.73 \mathrm{bc}$ & $7.00 \pm 2.73 \mathrm{~cd}$ & $6.00 \pm 2.23 \mathrm{~d}$ & $8.00 \pm 2.73 \mathrm{~d}$ \\
\hline Calotropis procera & $0.00 \pm 0.00 \mathrm{~b}$ & $1.00 \pm 2.23 \mathrm{~d}$ & $2.00 \pm 2.73 \mathrm{e}$ & $2.00 \pm 2.73 \mathrm{ef}$ & $4.00 \pm 2.23 \mathrm{~d}$ & $6.00 \pm 2.23 \mathrm{~d}$ \\
\hline Control & $0.00 \pm 0.00 \mathrm{~b}$ & $0.00 \pm 0.00 \mathrm{~d}$ & $0.00 \pm 0.00 \mathrm{e}$ & $0.00 \pm 0.00 \mathrm{f}$ & $0.00 \pm 0.00 \mathrm{e}$ & $0.00 \pm 0.00 \mathrm{e}$ \\
\hline LSD Value & 2.56 & 3.28 & 3.37 & 3.54 & 3.71 & 3.19 \\
\hline
\end{tabular}

Each value is a mean \pm standard error of five replications. Means followed by the same letters along the column are not significantly different at $(\mathrm{P}>0.05)$ using LSD Test 
Table 3. Mean cumulative mortality (\%) of maize weevil due to different plant aqueous extracts and its varying concentrations on maize grains after 3 days exposure period

\begin{tabular}{|c|c|c|c|c|c|c|}
\hline \multirow{2}{*}{ Treatments } & \multicolumn{6}{|c|}{ Concentrations (\%) } \\
\hline & 0.5 & 1 & 1.5 & 2 & 2.5 & 3 \\
\hline Azadirachta indica & $12.00 \pm 2.73 \mathrm{a}$ & $13.00 \pm 2.73 \mathrm{a}$ & $15.00 \pm 3.53 \mathrm{a}$ & $22.00 \pm 2.73 \mathrm{a}$ & $26.00 \pm 4.18 \mathrm{a}$ & $43.00 \pm 4.47 \mathrm{a}$ \\
\hline Caralluma tuberculata & $2.00 \pm 2.73 \mathrm{~cd}$ & $3.00 \pm 2.73 \mathrm{~cd}$ & $5.00 \pm 3.53 \mathrm{~cd}$ & $8.00 \pm 2.73 \mathrm{c}$ & $8.00 \pm 2.73 \mathrm{c}$ & $12.00 \pm 2.73 \mathrm{~d}$ \\
\hline Allium sativum & $6.00 \pm 2.23 \mathrm{~b}$ & $7.00 \pm 2.73 \mathrm{~b}$ & $9.00 \pm 2.23 \mathrm{bc}$ & $10.00 \pm 3.53 \mathrm{c}$ & $14.00 \pm 4.18 b$ & $19.00 \pm 2.23 \mathrm{c}$ \\
\hline Curcuma longa & $8.00 \pm 2.73 b$ & $12.00 \pm 2.73 \mathrm{a}$ & $13.00 \pm 2.73 \mathrm{ab}$ & $16.00 \pm 4.18 b$ & $22.00 \pm 2.73 \mathrm{a}$ & $27.00 \pm 2.73 b$ \\
\hline Citrullus colocynthis & $5.00 \pm 3.53 \mathrm{bc}$ & $6.00 \pm 2.23 \mathrm{bc}$ & $7.00 \pm 2.73 \mathrm{~cd}$ & $8.00 \pm 2.73 \mathrm{c}$ & $10.00 \pm 3.53 \mathrm{bc}$ & $18.00 \pm 2.73 \mathrm{c}$ \\
\hline Calotropis procera & $2.00 \pm 2.73 \mathrm{~cd}$ & $2.00 \pm 2.73 \mathrm{~d}$ & $4.00 \pm 5.47 \mathrm{de}$ & $7.00 \pm 2.73 \mathrm{c}$ & $7.00 \pm 2.73 c$ & $10.00 \pm 3.53 \mathrm{~d}$ \\
\hline Control & $0.00 \pm 0.00 \mathrm{~d}$ & $0.00 \pm 0.00 \mathrm{~d}$ & $0.00 \pm 0.00 \mathrm{e}$ & $0.00 \pm 0.00 \mathrm{~d}$ & $0.00 \pm 0.00 \mathrm{~d}$ & $0.00 \pm 0.00 \mathrm{e}$ \\
\hline LSD Value & 3.37 & 3.19 & 4.24 & 3.79 & 4.09 & 3.79 \\
\hline
\end{tabular}

Each value is a mean \pm standard error of five replications. Means followed by the same letters along the column are not significantly different at (P>0.05) using LSD Test

Table 4. Mean cumulative mortality $(\%)$ of maize weevil due to different plant aqueous extracts and its varying concentrations on maize grains after 7 days exposure period

\begin{tabular}{|c|c|c|c|c|c|c|}
\hline \multirow{2}{*}{ Treatments } & \multicolumn{6}{|c|}{ Concentrations (\%) } \\
\hline & 0.5 & 1 & 1.5 & 2 & 2.5 & 3 \\
\hline Azadirachta indica & $27.00 \pm 2.73 \mathrm{a}$ & $40.00 \pm 3.53 \mathrm{a}$ & $52.00 \pm 2.73 \mathrm{a}$ & $65.00 \pm 3.53 \mathrm{a}$ & $69.00 \pm 2.23 \mathrm{a}$ & $78.00 \pm 2.73 \mathrm{a}$ \\
\hline Caralluma tuberculata & $8.00 \pm 2.73 \mathrm{c}$ & $12.00 \pm 2.73 \mathrm{e}$ & $18.00 \pm 2.73 \mathrm{e}$ & $22.00 \pm 2.73 \mathrm{~d}$ & $23.00 \pm 2.73 \mathrm{e}$ & $27.00 \pm 2.73 \mathrm{e}$ \\
\hline Allium sativum & $14.00 \pm 2.23 \mathrm{~b}$ & $24.00 \pm 2.23 \mathrm{c}$ & $30.00 \pm 3.53 \mathrm{c}$ & $35.00 \pm 3.53 \mathrm{c}$ & $45.00 \pm 3.53 \mathrm{c}$ & $50.00 \pm 3.53 \mathrm{c}$ \\
\hline Curcuma longa & $24.00 \pm 4.18 \mathrm{a}$ & $36.00 \pm 4.18 b$ & $46.00 \pm 4.18 b$ & $45.00 \pm 3.53 \mathrm{~b}$ & $62.00 \pm 2.73 \mathrm{~b}$ & $70.00 \pm 3.53 \mathrm{~b}$ \\
\hline Citrullus colocynthis & $12.00 \pm 2.73 \mathrm{~b}$ & $17.00 \pm 2.73 \mathrm{~d}$ & $24.00 \pm 2.23 \mathrm{~d}$ & $25.00 \pm 3.53 \mathrm{~d}$ & $35.00 \pm 6.12 \mathrm{a}$ & $39.00 \pm 4.18 \mathrm{~d}$ \\
\hline Calotropis procera & $6.00 \pm 2.23 \mathrm{c}$ & $7.00 \pm 2.73 \mathrm{f}$ & $9.00 \pm 2.23 \mathrm{f}$ & $13.00 \pm 2.73 \mathrm{e}$ & $15.00 \pm 3.15 \mathrm{f}$ & $21.00 \pm 2.23 \mathrm{~d}$ \\
\hline Control & $0.00 \pm 0.00 \mathrm{~d}$ & $2.00 \pm 2.73 \mathrm{~g}$ & $2.00 \pm 2.73 \mathrm{~g}$ & $1.00 \pm 2.23 \mathrm{f}$ & $2.00 \pm 2.73 \mathrm{~g}$ & $2.00 \pm 2.73 \mathrm{~g}$ \\
\hline LSD Value & 3.46 & 3.94 & 3.87 & 4.09 & 4.64 & 4.09 \\
\hline
\end{tabular}

Each value is a mean \pm standard error of five replications. Means followed by the same letters along the column are not significantly different at (P>0.05) using LSD Test 
Table 5. Mean cumulative mortality (\%) of maize weevil due to different plant aqueous extracts and its varying concentrations on maize grains after 14 days exposure period

\begin{tabular}{|c|c|c|c|c|c|c|}
\hline \multirow{2}{*}{ Treatments } & \multicolumn{6}{|c|}{ Concentrations (\%) } \\
\hline & 0.5 & 1 & 1.5 & 2 & 2.5 & 3 \\
\hline Azadirachta indica & $37.00 \pm 4.47 \mathrm{a}$ & $52.00 \pm 2.73 \mathrm{a}$ & $69.00 \pm 4.18 \mathrm{a}$ & $75.00 \pm 3.53 \mathrm{a}$ & $82.00 \pm 2.73 \mathrm{a}$ & $88.00 \pm 2.73 \mathrm{a}$ \\
\hline Caralluma tuberculata & $8.00 \pm 2.73 \mathrm{e}$ & $14.00 \pm 2.23 \mathrm{e}$ & $23.00 \pm 2.73 \mathrm{e}$ & $26.00 \pm 2.23 \mathrm{e}$ & $29.00 \pm 4.18 \mathrm{e}$ & $30.00 \pm 3.53 \mathrm{e}$ \\
\hline Allium sativum & $19.00 \pm 4.18 \mathrm{c}$ & $29.00 \pm 4.18 \mathrm{c}$ & $42.00 \pm 2.73 \mathrm{c}$ & $41.00 \pm 4.18 \mathrm{c}$ & $45.00 \pm 3.53 \mathrm{c}$ & $53.00 \pm 2.73 \mathrm{c}$ \\
\hline Curcuma longa & $30.00 \pm 5.00 \mathrm{~b}$ & $46.00 \pm 2.23 \mathrm{~b}$ & $53.00 \pm 2.73 \mathrm{~b}$ & $63.00 \pm 2.73 \mathrm{~b}$ & $70.00 \pm 3.53 \mathrm{~b}$ & $78.00 \pm 2.73 \mathrm{~b}$ \\
\hline Citrullus colocynthis & $13.00 \pm 2.73 \mathrm{~d}$ & $22.00 \pm 2.73 \mathrm{~d}$ & $28.00 \pm 4.47 \mathrm{~d}$ & $31.00 \pm 4.18 \mathrm{~d}$ & $38.00 \pm 2.73 \mathrm{~d}$ & $40.00 \pm 3.53 \mathrm{~d}$ \\
\hline Calotropis procera & $7.00 \pm 2.73 \mathrm{e}$ & $10.00 \pm 3.53 \mathrm{f}$ & $14.00 \pm 2.23 \mathrm{f}$ & $18.00 \pm 2.73 \mathrm{f}$ & $20.00 \pm 3.53 \mathrm{f}$ & $23.00 \pm 2.73 \mathrm{f}$ \\
\hline Control & $1.00 \pm 2.23 \mathrm{f}$ & $2.00 \pm 2.73 \mathrm{~g}$ & $2.00 \pm 2.73 \mathrm{~g}$ & $1.00 \pm 2.23 \mathrm{~g}$ & $2.00 \pm 2.73 \mathrm{~g}$ & $2.00 \pm 2.73 \mathrm{~g}$ \\
\hline LSD Value & 4.64 & 3.87 & 4.16 & 4.16 & 4.31 & 3.87 \\
\hline
\end{tabular}

Each value is a mean \pm standard error of five replications. Means followed by the same letters along the column are not significantly different at (P>0.05) using LSD Test

Table 6. Mean cumulative mortality $(\%)$ of maize weevil due to different plant aqueous extracts and its varying concentrations on maize grains after 21 days exposure period

\begin{tabular}{|c|c|c|c|c|c|c|}
\hline \multirow{2}{*}{ Treatments } & \multicolumn{5}{|c|}{ Concentrations (\%) } \\
\cline { 2 - 7 } & $\mathbf{0 . 5}$ & $\mathbf{1}$ & $\mathbf{1 . 5}$ & $\mathbf{2}$ & $\mathbf{2 . 5}$ & $\mathbf{3}$ \\
\hline Azadirachta indica & $42.00 \pm 4.47 \mathrm{a}$ & $56.00 \pm 4.18 \mathrm{a}$ & $73.00 \pm 2.73 \mathrm{a}$ & $78.00 \pm 2.73 \mathrm{a}$ & $87.00 \pm 2.73 \mathrm{a}$ & $95.00 \pm 3.53 \mathrm{a}$ \\
\hline Caralluma tuberculata & $11.00 \pm 4.18 \mathrm{e}$ & $20.00 \pm 3.53 \mathrm{e}$ & $28.00 \pm 2.73 \mathrm{~d}$ & $30.00 \pm 3.53 \mathrm{e}$ & $33.00 \pm 4.47 \mathrm{e}$ & $35.00 \pm 3.53 \mathrm{~d}$ \\
\hline Allium sativum & $24.00 \pm 4.18 \mathrm{c}$ & $33.00 \pm 2.73 \mathrm{c}$ & $47.00 \pm 2.73 \mathrm{c}$ & $46.00 \pm 4.18 \mathrm{c}$ & $54.00 \pm 4.18 \mathrm{c}$ & $60.00 \pm 3.53 \mathrm{~b}$ \\
\hline Curcuma longa & $35.00 \pm 5.00 \mathrm{~b}$ & $48.00 \pm 2.73 \mathrm{~b}$ & $56.00 \pm 4.18 \mathrm{~b}$ & $67.00 \pm 2.73 \mathrm{~b}$ & $70.00 \pm 3.53 \mathrm{~b}$ & $91.00 \pm 4.18 \mathrm{a}$ \\
\hline Citrullus colocynthis & $18.00 \pm 2.73 \mathrm{~d}$ & $26.00 \pm 4.18 \mathrm{~d}$ & $29.00 \pm 4.18 \mathrm{~d}$ & $36.00 \pm 4.18 \mathrm{~d}$ & $43.00 \pm 4.47 \mathrm{~d}$ & $48.00 \pm 2.73 \mathrm{c}$ \\
\hline Calotropis procera & $10.00 \pm 3.53 \mathrm{e}$ & $12.00 \pm 2.73 \mathrm{f}$ & $16.00 \pm 4.18 \mathrm{e}$ & $21.00 \pm 2.23 \mathrm{f}$ & $20.00 \pm 3.53 \mathrm{f}$ & $26.00 \pm 2.23 \mathrm{e}$ \\
\hline Control & $1.00 \pm 2.23 \mathrm{f}$ & $2.00 \pm 2.73 \mathrm{~g}$ & $2.00 \pm 2.73 \mathrm{f}$ & $1.00 \pm 2.23 \mathrm{~g}$ & $2.00 \pm 2.73 \mathrm{~g}$ & $2.00 \pm 2.73 \mathrm{f}$ \\
\hline LSD Value & 5.01 & 4.31 & 4.44 & 4.16 & 4.83 & 4.24 \\
\hline
\end{tabular}

Each value is a mean \pm standard error of five replications. Means followed by the same letters along the column are not significantly different at $(\mathrm{P}>0.05)$ using LSD Test 


\section{Discussion}

A superior entomocidal effectiveness of $A$. indica and $C$. longa plant aqueous extracts against maize weevil was observed in present study. These results are in conformity with the previous studies in which $A$. indica extracts were found most effective against maize weevil [12]. These results also confirm the findings of previous workers who reported that neem extracts carry insecticidal properties against Cylas puncticollis in Potato tuber. Neem oil caused $100 \%$ mortality whereas neem leaves extract produced moderate mortality of the tested insects [13]. Similarly, $C$. longa has been reported to carry insecticidal and repellent properties against, Spodoptera frugiperda and S. zeamais. The $C$. longa extracts caused complete mortality of maize weevil after 6 days of contact with Arturmerone at $1 \%\left(\mathrm{~mm}^{-1}\right)$ while $58 \%$ mortality of $S$. frugiperda. The $S$. frugiperda caterpillars exposed to ar-turmerone were $60.0 \%$ and $93.8 \%$ lower than control caterpillars, respectively. The direct contact of arturmerone on target insect achieved 100 percent mortality [5]. Whereas, in our study turmeric extracts caused significant mortality of adult weevils. Similarly, previous studies showed that seed extract of black pepper, Piper guineese, prepared in different solvents and found that acetone extract had highest toxicity $(100 \%)$ while aqueous extract had low toxic effect [11]. The extracts prepared from ar-turmerone ( $C$. longa) have been reported to cause 60.0 and $93.8 \%$ control of maize weevil. All the other evaluated extracts resulted into less than $50 \%$ mortality of weevils except $A$. indica extracts at 15000, 20000 and 25000ppm [7].

According to our findings $A$. indica extracts caused $95 \%$ mortality followed by $C$. longa $(91 \%)$ extracts at highest concentration of $3 \%$. The array of toxicity was found as A. indica (98.00\%) > Polygonum hydropiper (94.43\%) $>$ Nerium oleander $(56.63 \%)>C$. procera $>$ Annonareticulate. Mortality percentage was found directly proportional to exposure time after treatment. The A. sativum plant extracts were found effective against larvae of Scyphophorus acupuntatus along with other plant extracts. Maximum mortality of maize weevil was found by using $A$. mexicana (53\%), A. sativum (43\%) and T. erecta plant extracts [14].

In entomocidal effect study chemical constituents are involved which affect the biology and survival of insect pests. Similar results have been reported by different scientists in which neem extracts were found effective against different stored grain insect pests which have been attributed to the presence of many phyto-chemicals such as Azadirachtin, triterpenoids, meliantriol, salanin etc. [15]. Similarly, C. longa extracts have been reported to carry many phytochemicals such as Curcuminoids, monoterpinoids, terpenoids, odoriferous oils and oleoresins, turmerone and arturmeronephyto-chemicals constituents which strongly affect as repellant and antifeedent against stored grain insect pests [16-18]. The C. longa extracts having ar-turmerone caused maximum mortality of maize weevil [19]. The mortality of maize weevil increased by increasing the concentration of essential oils of $C$. longa. These findings agree to the present study in which the highest concentration $(3 \%)$ exhibited the maximum mortality $(91 \%)$ of tested insect. The $A$. sativum extracts possess flavonoids (Rutins) and sulfur compounds including allicine which affect the feeding behavior of noctuid larvae [12].

\section{Conclusion and recommendations}

Hence, it is concluded that $A$. indica and $C$. longa aqueous extracts are most effective against maize weevil and could be utilized as phyto-chemicals against maize weevil.

\section{Authors' contributions}

Conceived and designed the experiments: MM Rashid, Performed the experiments: Riazuddin, Analyzed the data and reviewed 
the paper. M Tariq, AA Khan \& MQ Kakar.

\section{Acknowledgement}

The authors are thankful to Pakistan Science Foundation (PSF), Islamabad, Pakistan for providing financial support for this study under Grant No. PSF/NSLP/KP-GU (424).

\section{References:}

1. Adedire CO, Obembe OM, Akinkurolere RO \& Oduleye SO (2011). Response of Callosobruchus maculatus (Coleoptera: Chrysomelidae: Bruchinae) to extracts of cashew kernels. J Plant Dis and Prot 1(18): 75-79.

2. Arifuzzaman M, AlBachchu MA, Kulsum MO \& Ara R (2016). Toxicity and repellency effect of some indigenous plant extracts against lesser grain borer, Rhyzopertha dominica (F.) (Coleoptera: Bostrychidae). J Bio-Sci 22: 31-39.

3. Asawalam EF, Emosairue SO, Ekeleme F \& Wokocha R (2007). Efficacy of Piper guineense (Schum \& Thonn) seed extract against maize weevil, Sitophilus zeamais (Motschulsky) as influenced by different extraction solvents. Inter J Pest Manag 53: 1-6.

4. Bhardwaj KS, Bhardwaj RS, Ranjeet D \& Ganesh N (2011). Curcuma longa leaves exhibits a potential antioxidant, antibacterial and immunomodulating properties. Inter J Phytomed 3: 270-277.

5. Castro-Álvarez FF, William M, Bergvinson DJ \& García-Lara S (2015). Genetic mapping of QTL for maize weevil resistance in a RIL population of tropical maize. Theo Appl Genetics 1(28): 411-419.

6. Chebet, F, Deng, AL, Ogendo, JO, Kamau, AW, \& Bett PK (2013). Bioactivity of selected plant powders against Prostephanus truncatus (Coleoptera: Bostrichidae) in stored maize grains. Plant Protec Sci 49(1): 3443.

7. De-Souza TW, De-Sousa FS, Grazziotti GH, Parente LML, Lião LM \& Zanuncio
JC (2013). Ar-turmerone from Curcuma longa (Zingiberaceae) rhizomes and effects on Sitophilus zeamais (Coleoptera: Curculionidae) and Spodoptera frugiperda (Lepidoptera: Noctuidae). Indus Crops Prod 46: 158-164.

8. Hori M \& Kasaishi Y (2005). Estimation of the phosphine resistance level of the cigarette beetle, Lasioderma serricorne (Fabricius) (Coleoptera: Anobiidae), by the knockdown time of adult. Appl Entomol Zool 40: 557-561.

9. Ileke K \& Oni M (2011). Toxicity of some plant powders to maize weevil, Sitophilus zeamais (Motschulsky) [Coleoptera: Curculiondae] on stored wheat grains (Triticum aestivum). Afr J Agric Res 6: 3043-3048.

10. Isah, MD, Abdullahi, G \& Sastawa BM (2012). Distribution patterns of insect pests infesting some field and stored commodities in Maiduguri, North-Eastern Nigeria: Implications for their management. J Appl Res Technol 1: 227.

11. Islam T, Iqbal J, Abdullah K \& Khan EA (2017). Evaluation of some plant extracts against maize weevil, Sitophilus zeamais (Coleoptera: Curculionidae) under laboratory conditions. Pak J Agri Sci 54: 737-741.

12. Khan H, Marwat KB, Khan MA \& Hashim S (2014). Herbicidal control of parthenium weed in maize. Pak J Bot 46: 497-504.

13. Lee BH, Choi WS, Lee SE \& Park BS (2001). Fumigant toxicity of essential oils and their constituent compounds towards the rice weevil, Sitophilus oryzae (L.). Crop Protec 20: 317-320.

14. Mallavadhani U, Prasad BR, Soujanya PL, Rao B \& Ratanlal M (2016). Aloe vera (L.) Burm. F: A highly useful Indian traditional plant for the management of maize storage pest, Sitophilus oryzae L.(Coleoptera: Curculionidae). J Biopest 9: 157-166. 
15. Mamoon-ur-Rashid, M., Abdullah K. Wajhi-ul-Abbas, Batool A. Hussain S \& Riaz-ud-din (2016). Species compositions and relative abundance of insect pests associated with stored maize in Dera Ismail Khan and its adjacent Punjab areas. Pak Entomol 38(2): 83-87.

16. Riaz-ud-Din, Mamoon-ur-Rashid, M, \& Mansoor M (2018). Repellent Responses of Maize Weevil, Sitophilus zeamais Motsch (Coleoptera: Curculionidae) towards Entomocidal Plant Products. Pak J Sci Indust Res Series B: Biol Sci 61(3): 165-172.

17. Minista I, Ngakou A, Younoussa L \& Nchiwan E (2017). Insecticidal efficacy of neem (Azadirachta indica A. Juss.) products against the sweet potato (Ipomea batatas L.) weevil (Cylas puncticollis Boh.) in storage. J Entomol Zool Stud 5(5): 1130-1137

18. Nawaz A, Ali Z, Aasi MS, Iqbal J \& Nadeem M (2017). Evaluation of quantitative losses of maize genotypes to Sitophilus zeamais (Motsch) (Coleoptera: Curculionidae) under laboratory conditions. J Agri Res 55(1): 55-63.

19. Nukenine EN, Adler C \& Reichmuth $C$ (2010). Efficacy of Clausena anisata and Plectranthus glandulosus leaf powder against Prostephanus truncatus (Coleoptera: Bostrichidae) and two strains of Sitophilus zeamais (Coleoptera: Curculionidae) on maize. J Pest Sci 83: 181-190. 